\title{
Satire as Strategy for Resistance and Persistence in A Series of Modest Pronouncements
}

\author{
Angela Sweigart-Gallagher and Melissa C. Thompson ${ }^{1}$
}

In "Satire as Strategy for Resistance and Persistence in A Series of Modest Pronouncements," Angela Sweigart-Gallagher and Melissa C. Thompson examine and analyze how their performance project $A$ Series of Modest Pronouncements created specifically for and as part of the nationwide performance movement Bad and Nasty fits within a broader landscape of contemporary political satire. They argue that their use of satirical performance tactics identified by Amber Day, such as merging the mimetic and the real and "identity nabbing" to create moments of what L.M. Bogad describes as "serious play." Sweigart-Gallagher and Thompson argue these techniques create a performance structure that encourages audiences to deconstruct the political messages they receive, thus motivating them to resist the outright misogyny, racism, and xenophobia at the core of the Trump administration. Further, they suggest that satirical performance serves as a strategy for creating coalitions with other progressive performeractivists and mobilizing resistance-based artists and audiences as a means to resist and persist throughout the remainder of Trump's term in office. [Article copies available for a fee from The Transformative Studies Institute. E-mail address: journal@transformativestudies.org Website: http://www.transformativestudies.org (02019 by The Transformative Studies Institute. All rights reserved.]

KEYWORDS: Political Satire, Feminist Performance, Resistance.

"Satirizing figures and structures of power spans the history of civilization. Sometimes you need to take a situation seriously enough to make fun of it." -L.M. Bogad, Tactical Performance, (62)

\footnotetext{
${ }^{1}$ Angela Sweigart-Gallagher is an assistant professor of theatre at St. Lawrence University.

Melissa C. Thompson is an assistant professor of performing arts at the University of Maine-Farmington.

Acknowledgements: Angela Sweigart-Gallagher received funding from St. Lawrence University to support her research and performance work.
} 